\title{
High School Students' Career Decision-making Difficulties According to Locus of Control
}

\author{
Oğuzhan Kırdök ${ }^{1, *}$, Esranur Harman ${ }^{2}$ \\ ${ }^{1}$ Faculty of Education, Çukurova University, Turkey \\ ${ }^{2}$ Provincial Directorate of National Education, Turkey
}

Copyright $(\mathrm{C} 2018$ by authors, all rights reserved. Authors agree that this article remains permanently open access under the terms of the Creative Commons Attribution License 4.0 International License

\begin{abstract}
This study intends to elaborate upon difficulties in career decisions of high school students with different locus of control. 9th, 10th, 11th and 12th grade students aged 14-19, $282(\% 55.4)$ females, $227(\% 44.6)$ males totaling 509 participants involved in research located in the south of Turkey. Career Decision-Making Difficulties Questionnaire (CDDQ) and Rotter Internal-External Locus of Control Scale (RIEFCS) were used to collect data. One-way analysis of variance was conducted to compare the participants' career decisionmaking difficulties in accordance with the locus of control. The findings indicate that total points obtained from the scale of career decision-making difficulties of the participants with external locus of control and lack of information of the scale with inconsistent information sub-dimensions have a higher score average than students with internal locus of control. Individuals with external locus of control experienced more difficulty in the process of decision-making due to the lack of necessary information or inconsistent information. This study contributes to practitioners working in the field of career for theory or application.
\end{abstract}

Keywords Career Decision-making Difficulties, Locus of Control, High-school Students

\section{Introduction}

Adolescence spanning high school years is a critical period in the course of life. During this period, important decisions are taken for life and adolescents are expected to gain an occupational identity. Choice of profession is one of the basic developmental tasks for adolescents. Adolescents question which profession they will be heading to and strive to obtain an occupational identity. However, since rapid changes at the present time and technological developments affect individuals' perceptions regarding career and occupation, these factors can cause difficulties while making career decisions. Mounting evidence has revealed that adolescents and college students have difficulty in career decision-making $[1,2,5,13,29$, $32,37,45$, and 47]. Individuals experiencing career decision-making difficulties may make an inappropriate decision or impede the decision-making process [17].

Career decision-making difficulties are the problems that need to be dealt with before making career decision [3]. Gati, Krausz \& Osipow [17], have examined the facets of career decision-making difficulties called career decision-making taxonomy. This category consists of three sub-categories: lack of readiness, lack of information and inconsistent information. Lack of readiness is defined as difficulties encountered by individuals in the process of career decision-making. Lack of readiness arises from lack of motivation, general indecisiveness and dysfunctional beliefs. Lack of information is difficulties deriving from insufficient information encountered while individuals make decisions. These difficulties stem from lack of information about decision-making process, self, occupations and ways of obtaining additional information. Inconsistent information is decision-making difficulties emerging with internal and external conflicts with the effect of unreliable information. The factors described in this taxonomy may cause individuals to encounter difficulties before and during decision-making [33].

Career decision-making difficulties may be affected by problem solving and decision-making skills of individuals. Adolescents lacking problem solving and decision-making skills tend to experience more difficulty in decisionmaking [8]. The support that they perceive from the family of adolescents, their friends, the environment [33], devotion to the family and friendship [42] affects their decision making processes. Various studies show that career decision making difficulties are related to environmental and individual characteristics such as negative beliefs related to choice of education $[2,5]$, five factor personality traits [12], emotional and personality traits [37], self-efficacy perception [29], parental styles [43], emotional intelligence [11], psychological stability 
[41].

\subsection{Career Decision-making and Locus of Control}

Some adolescents also need the support of others in the decision-making process and self-confidence problem [40]. In this sense, the importance of individual factors in the career decision-making process occurs [46]. Locus of control is one of the factors that influence career decision-making difficulty. Individuals' locus of control plays an important role in the process of decision-making and may affect decision-making behavior directly $[14,28$, 31]. However some individuals in the process of decision-making believe that control related to decision-making behavior is internal; others believe that it depends on external factors. Depending on individuals' internal or external locus of control, behavior of the decision process can also be differentiated. Locus of control is a consequence of a facet that refers to the outcome of an individuals' behaviors being in their own or in control of outsiders [10]. Internally control-oriented adolescents are aware that the decision belongs to their own and assume responsibility for the decisions. However, due to the fact that external control-oriented adolescents believe that luck, fate or other people controlled their life, they may not come to the process of decision-making [19]. They think that success or failure is ascribed to factors outside themselves; they will not be able to change the results themselves [20]. Several studies show that high school and university students with an external locus of control may experience career indecision [24, 32, 44]. Çoban \& Hamamc1 [7] maintain that students with internal locus of control use more logical strategies in the process of decision-making and have less indecision. According to Gati, Gadassi, Saka et al. [18] internal locus of control is related to low career decision-making difficulty. In addition, an increase in the external locus of control complicates career decision-making process [36]. Individuals with dysfunctional beliefs about the choice of occupation to be influenced by factors other than themselves are more likely to experience difficulty in making decisions [2]. These studies suggest that individuals with external locus of control experience difficulties in deciding on the occupation, and that these individuals influence their career-planning success and adaptations in the decision-making process [44].

\subsection{Career Decision-making Process in Turkey}

In Turkey, the two stages of occupational decision processes are important for decision-making. The former is the decision of the high school at the end of secondary school, and the latter is taken if you graduate from the university and obtain the required score from the university exam. The occupational decision to be taken, especially as a result of the high school years, is seen as a fundamental orientation that will affect their future life. As mentioned above, various social and individual characteristics of adolescents influence this decision. A similar situation exists in Turkey, but there is a significant impact on the decision making process of the family and the community in a Turkish culture with a collectivist structure $[23,25,30$, and 34]. While making their future career plans, students can be under the pressure of choosing the occupation their families predestined for them irrespective of their own desires and of going on the profession of their fathers [39]. In this process, where the family and the environment are influenced, the locus of control of the adolescent is seen as an even more important individual facet.

In line with the studies mentioned above, this study aim to focus on career decision-making difficulties associated with the concept of locus of control. In Turkey, there have been few studies that examine the relationship of career decision-making difficulties and locus of control of high school students, and therefore it remains important to carry out this research. The aim of this research is to show whether high school students with different locus of control varied in terms of difficulty they experienced during career decision-making.

\section{Method}

\subsection{Study Group}

A total of 509 students, 282 (55.4\%) females and 227 (44.6\%) males, attending two different Anatolian schools affiliated to the Ministry of National Education, participated in the research. The age of students participating in the study ranged from 14 to 19 and the average age was $16.08 .29 .7 \%(\mathrm{n}=151)$ of the students were in the 9th grade, $24.6 \%(\mathrm{n}=125)$ were in the 10th grade, $27.9 \%(\mathrm{n}=142)$ were in the 11 th grade and $17.9 \%(\mathrm{n}=91)$ were in the 12th grade.

\subsection{Measures}

Career Decision-Making Difficulties Questionnaire (CDDQ): The scale developed for high school students by Gati \& Saka [15] is a five-point Likert-type scale adapted to Turkish by Bacanlı [4]. The two items of the scale are fillers and consist of 34 items. An increase in the score from CDDQ means an increase in career decision making difficulty. An ADDTREE analysis was conducted just as in the original version in order to identify the construct validity of the scale. There are three sub-scales of the scale: lack of readiness, lack of information and inconsistent information. These subscales also consist of ten subcategories. Cronbach alpha internal consistency coefficients of scale was .45 for the lack of readiness category, and .90 for the lack of information category, and .82 for the inconsistent information category and .82 for the whole scale [4].

Rotter's Internal-External Locus of Control Scale 
(RIEFCS): Rotter's Internal-External Locus of Control Scale is used to measure the locus of control of individuals. The adaptation to Turkish was done by Dağ [9]. The scale consists of 29 items (6 of which are fillers) and has two options. One of the options measures the internal locus of control and the other external locus of control. Scale scores ranged from 0-23. Rising scores indicate an increase in beliefs of external locus of control. It was determined that the scale has only one dimension in basic components analysis for construct validity. In the analysis for criterion dependent validity, a negative correlation with the self-control scale was found. The total item score correlations of the scale ranged from .11 to .48. The Cronbach alpha internal consistency coefficient was .77, and the reliability coefficient calculated by KR-20 technique was .68. The two-half test reliability coefficient of the scale was also reported to be between .65 and .79 in various samples. The test-retest reliability coefficient ranges from .49 to .83 .

\subsection{Data Analysis}

Data collected via data collection tools were analyzed via SPSS 20. One way analysis of variance was conducted to compare the career decision making difficulties of the students according to their locus of control. Post hoc analysis (Scheffe) was performed to reveal the source of variance.

\section{Results}

In order to examine the participants' career decision-making difficulties by their locus of control, a standard deviation score $(\mathrm{Sd}=3.46)$ was added to the arithmetic mean of locus of control scores of the study group $(\overline{\mathrm{x}}=11.42)$; arithmetic mean $(\overline{\mathrm{x}}=14.88)$ and the ones above were identified as external locus of control, a standard deviation score $(\mathrm{Ss}=3.46)$ was subtracted from the arithmetic mean $(\overline{\mathrm{X}}=11.42)$ and the arithmetic mean
$(\overline{\mathrm{X}}=14.88)$ and the ones were identified as internal locus of control. Those between these two values are defined as uncertain. The arithmetic mean, standard deviation and standard error values of students' scores of career decision-making difficulties according to their locus of control are shown in Table 1.

As shown in Table 1, the average of the total scores of the students with external locus of control on career decision-making difficulties is 98.68 , and the average of the total scores of internal locus of control of the students on career decision-making difficulties is 83.57. The average score of the students with external locus of control on lack of readiness is 35.21 , and the average of the scores of the students with internal locus of control on lack of readiness is 33.96. The average score of students with external locus of control on lack of knowledge is 35.75 , and the average score of students with internal locus of control on lack of knowledge is 28.40 . The average score of students with external locus of control on inconsistent information is 27.72 and the average score of students with internal locus of control on inconsistent information is 21.21. One-way analysis of variance to examine whether the difference between the students' career decision-making difficulty scores by locus of control is significant is shown in Table 1.

As shown in Table 1, there was a significant difference in the total score between lack of information of career decision-making difficulties scale and inconsistent information sub-dimensions $(\mathrm{p}<.001)$. The Scheffe Test was applied in order to identify the source of the variance. According to Scheffe Test result, scores of students who have external locus of control were found higher. However, there was no significant difference in the lack of readiness sub-scale according to the locus of control. According to these findings, it can be said that students with external locus of control have experienced more lack of information, inconsistent information difficulties and career decision-making difficulties than internal control students.

Table 1. Results of ANOVA on Total and Sub-scales of Participants' Career Decision-Making Difficulties by Locus of Control

\begin{tabular}{|c|c|c|c|c|c|c|c|}
\hline \multicolumn{2}{|c|}{ Locus of Control } & $\mathrm{N}$ & $\overline{\mathrm{X}}$ & SD & $\mathrm{F}$ & $\mathrm{p}$ & $\begin{array}{l}\text { The source of the } \\
\text { difference }\end{array}$ \\
\hline \multirow{3}{*}{ Lack of readiness } & Internal control & 67 & 33.96 & 4.42 & 2.047 & .130 & - \\
\hline & Uncertain & 338 & 34.1 & 5.18 & & & \\
\hline & External control & 104 & 35.21 & 5.43 & & & \\
\hline \multirow{3}{*}{ Lack of information } & Internal control & 67 & 28.4 & 11.21 & 8.943 & .000 & $\mathrm{i}<\mathrm{e}$ \\
\hline & Uncertain & 338 & 31.88 & 11.25 & & & \\
\hline & External control & 104 & 35.75 & 11.83 & & & \\
\hline \multirow{3}{*}{ Inconsistent information } & Internal control & 67 & 21.21 & 7.63 & 12.82 & .000 & $\mathrm{i}<\mathrm{e}$ \\
\hline & Uncertain & 338 & 24.21 & 8.65 & & & \\
\hline & External control & 104 & 27.72 & 8.31 & & & \\
\hline \multirow{3}{*}{ CDDQ Total } & Internal control & 67 & 83.57 & 18.67 & 11.739 & .000 & $\mathrm{i}<\mathrm{e}$ \\
\hline & Uncertain & 338 & 90.19 & 20.81 & & & \\
\hline & External control & 104 & 98.68 & 21.54 & & & \\
\hline
\end{tabular}


Table 2. Results of ANOVA on Subcategories of Career Decision-Making Difficulties by Locus of Control

\begin{tabular}{|c|c|c|c|c|c|c|c|}
\hline & Locus of Control & $\mathrm{N}$ & $\overline{\mathrm{X}}$ & $\mathrm{SD}$ & $\mathrm{F}$ & $\mathrm{p}$ & $\begin{array}{c}\text { The source of the } \\
\text { difference }\end{array}$ \\
\hline \multirow{3}{*}{ Lack of motivation } & Internal control & 67 & 6.21 & 2.52 & 5.108 & .006 & $\mathrm{i}<\mathrm{e}$ \\
\hline & Uncertain & 338 & 6.53 & 2.76 & & & \\
\hline & External control & 104 & 7.42 & 3.09 & & & \\
\hline \multirow{3}{*}{ General indecisiveness } & Internal control & 67 & 9.27 & 2.85 & 1.471 & .231 & - \\
\hline & Uncertain & 338 & 9.36 & 2.79 & & & \\
\hline & External control & 104 & 9.88 & 2.98 & & & \\
\hline \multirow{3}{*}{ Dysfunctional beliefss } & Internal control & 67 & 14.18 & 3.16 & 1.373 & .254 & - \\
\hline & Uncertain & 338 & 13.9 & 3.19 & & & \\
\hline & External control & 104 & 13.41 & 3.19 & & & \\
\hline \multirow{3}{*}{$\begin{array}{c}\text { Lack of information about the } \\
\text { process }\end{array}$} & Internal control & 67 & 6.76 & 3.18 & 4.622 & .010 & $\mathrm{i}<\mathrm{e}$ \\
\hline & Uncertain & 338 & 7.69 & 3.35 & & & \\
\hline & External control & 104 & 8.37 & 3.57 & & & \\
\hline \multirow{3}{*}{ Lack of information about self } & Internal control & 67 & 8.12 & 3.68 & 5.799 & .003 & $\mathrm{i}<\mathrm{e}$ \\
\hline & Uncertain & 338 & 9.18 & 3.97 & & & \\
\hline & External control & 104 & 10.2 & 4.08 & & & \\
\hline \multirow{3}{*}{$\begin{array}{c}\text { Lack of information about } \\
\text { occupations }\end{array}$} & Internal control & 67 & 6.88 & 3.04 & 8.992 & .000 & $\mathrm{i}<\mathrm{e}$ \\
\hline & Uncertain & 338 & 7.79 & 3.29 & & & \\
\hline & External control & 104 & 8.99 & 3.53 & & & \\
\hline \multirow{3}{*}{$\begin{array}{l}\text { Lack of Information about ways } \\
\text { of obtaining additional } \\
\text { information. }\end{array}$} & Internal control & 67 & 4.39 & 2.32 & 6.891 & .001 & $\mathrm{i}<\mathrm{e}$ \\
\hline & Uncertain & 338 & 4.66 & 2.31 & & & \\
\hline & External control & 104 & 5.54 & 2.41 & & & \\
\hline \multirow{3}{*}{ Unreliable information } & Internal control & 67 & 6.40 & 2.87 & 10.845 & .000 & $\mathrm{i}<\mathrm{e}$ \\
\hline & Uncertain & 338 & 7.06 & 3.11 & & & \\
\hline & External control & 104 & 8.45 & 3.28 & & & \\
\hline \multirow{3}{*}{ Internal conflicts } & Internal control & 67 & 11.01 & 3.92 & 10.980 & .000 & $\mathrm{i}<\mathrm{e}$ \\
\hline & Uncertain & 338 & 12.40 & 4.59 & & & \\
\hline & External control & 104 & 14.25 & 5.04 & & & \\
\hline \multirow{3}{*}{ External conflicts } & Internal control & 67 & 3.79 & 1.9 & 5.707 & .004 & $\mathrm{i}<\mathrm{e}$ \\
\hline & Uncertain & 338 & 4.75 & 2.5 & & & \\
\hline & External control & 104 & 5.02 & 2.44 & & & \\
\hline
\end{tabular}

As shown in Table 2, the average scores of the students with external locus of control in the subcategories of career decision-making difficulties are lack of motivation $(\overline{\mathrm{x}}$ $=7.42$ ), general indecisiveness $(\bar{x}=9.88)$, dysfunctional beliefs $(\overline{\mathrm{X}}=13.41)$, lack of information about the process $(\overline{\mathrm{X}}=8.37)$, lack of information about the self $(\overline{\mathrm{X}}=8.12)$, lack of information about the occupations $(\overline{\mathrm{X}}=8.99)$, lack of information about ways of obtaining additional information $(\overline{\mathrm{X}}=5.54)$, inconsistent information about the self and occupations $(\bar{x}=8.45)$, internal conflicts $(\bar{x}$ $=14.25)$,externalconflicts $(\overline{\mathrm{X}}=5.02)$. As shown in Table 2, the average scores of the students with external locus of control on the subcategories of career decision-making difficulties are lack of motivation $(\overline{\mathrm{x}}=7.42)$, general indecisiveness $(\overline{\mathrm{x}}=9.88)$, dysfunctional beliefs $(\overline{\mathrm{x}}$ $=13.41)$, lack of information about the process $(\overline{\mathrm{X}}=8.37)$, lack of information about the self $(\bar{x}=8.12)$, lack of information about the occupation $(\overline{\mathrm{x}}=8.99)$, lack of information about ways of obtaining additional information ( $\overline{\mathrm{x}}=5.54)$, inconsistent information about the self and occupations $(\bar{x}=8.45)$, internal conflicts $(\bar{x}$ $=14.25)$, external conflicts $(\overline{\mathrm{X}}=5.02)$.

In all subcategories except for the subcategory of dysfunctional beliefs of career decision-making difficulties scale, the highest arithmetic averages are seen in students with external locus of control. One way analysis of variance was performed to test the significance of the difference between the arithmetic mean. The results of the analysis of variance are shown in Table 2.

As shown in Table 2, a significant difference was found between lack of motivation $(\overline{\mathrm{X}}=7.42)$, lack of information about the process $(\overline{\mathrm{X}}=8.37)$, lack of information about the 
self $(\overline{\mathrm{X}}=8.12)$, lack of information about the occupations $(\overline{\mathrm{X}}=8.99)$, lack of information about ways of obtaining additional information $(\overline{\mathrm{X}}=5.54)$, inconsistent information about the self and occupations $(\overline{\mathrm{X}}=8.45)$, internal conflicts $(\overline{\mathrm{X}}=14.25)$, external conflicts $(\overline{\mathrm{X}}=5.02)$ subcategories of career decision-making difficulties scale according to students' locus of control.

The Scheffe Test was applied in order to identify the source of the variance. According to Scheffe Test result, the scores of the participants with external locus of control were found higher in all subcategories mentioned. But in the subcategories of general indecisiveness of the scale $(\overline{\mathrm{X}}$ $=9.88)$ and dysfunctional beliefs $(\bar{x}=13.41)$, significant differences could not be found by locus of control. According to these findings, the participants with external locus of control can be said to have epxerienced higher lack of motivation, lack of information about the process, lack of knowledge about the self, lack of information about the occupations, lack of information about ways of obtaining additional information, inconsistent information about the self and occupations, internal conflicts and external conflicts sourced career decision-making difficulty than the participants with internal locus of control .

\section{Discussion}

This study examined whether the difficulties of decision-making of high school students in accordance with their locus of control differed. The results show that the total scores of the students with external locus of control on career decision-making difficulty scale and the average scores on sub-scales of lack of information and inconsistent information were found to be higher than the students with internal locus of control. It can be argued that individuals with external locus of control experience more difficulties due to lack of information or inconsistency of the necessary information in career decision-making process. Students with external locus of control are more likely to experience career decision-making difficulties. This finding is consistent with Lease's [27] finding that students with external locus of control experience more career decision-making difficulty. The scores of the students from ten subcategories of career decision-making difficulty scale were examined by locus of control; scores of students with external locus of control were higher, excluding two subcategories. The difference in the four subcategories of the lack of information dimension is significant. Students with external locus of control have more difficulties due to lack of information about decision-making process, self, occupations and ways of obtaining additional information than students with internal locus of control. In addition, differences in three subcategories of inconsistent information dimension were also significant in favor of those with external locus of control. Students with external locus of control are experiencing more difficulties due to inconsistent information about themselves and their occupations, internal and external conflicts, than students with internal locus of control. This result can be attributed to the fact that individuals with internal locus of control use more of their logical decision-making strategy and therefore have less indecision [8]. Pečjak, \& Košir [35] show that students who provide more personal control experience have fewer career decision-making difficulties. Adolescents with external locus of control may be making fewer efforts when deciding, or they may expect an individual in their vicinity to make decisions on their behalf. These individuals may experience lack of confidence about their decision-making skills. Such situations will make the decision-making process difficult. Research shows that the higher the score of external locus of control, the higher the indecisiveness [32, 38]. Bacanl1 [2] is his study similarly found that outside forces were more effective in career decision-making that is, students with external control beliefs had more difficulty in career decision making.

Especially in a country where a collectivist culture predominates such as Turkey, it is predictable that the students with external control experience more difficulty. In vital crucial decisions, such as choosing spouses or choosing a career in Turkey, the family and the immediate environment are culturally very involved in the decisions of the individual [22]. If the person focuses on external locus of control, the external attribution of responsibility in this decision process will prevent the acquisition of necessary knowledge and skills for the decision. In case of decision making process, lack of information about the self or occupations may lead to indecisiveness [6]. However, individuals with internal locus of control are those who are more resistant to adverse effects when compared to individuals with external locus of control, who see themselves as effective and safe people, highly self-confident, and able to cope with environmentally responsible behaviors [48]. Adolescents with an internal locus of control will experience less difficulty by developing their professional knowledge and skills, taking their own responsibilities despite the pressures of the family and their environment. As a matter of fact, indecision is reduced in individuals who have improved their level of information about self and their occupations and have improved decision-making skills. Similarly, individuals with external locus of control who are in the direction of social reality are expected to experience different inconsistencies from different environments. Internalizing this information and passing it through their own filter will reduce the inconsistency of information and therefore the decision-making difficulty.

Lack of information and inconsistent information of high school students about the process, self and occupation constitute career decision-making difficulties. The information provided to these subjects and skills training also reduce their indecisiveness. However, these findings show that individuals with external control may experience 
more of these difficulties. It is also appropriate to conduct studies on locus of control in parallel with the studies of knowledge and skills aimed at the students' difficulties and indecisiveness' in career decision-making. Studies in school counseling services or in classroom guidance, need to take students' locus of control into account.

There was no significant difference between general indecisiveness and dysfunctional belief scores, which were categorized as lack of readiness, and locus of control, but there was a significant difference only in lack of motivation. Individuals with external locus of control may also experience lack of motivation to make decisions because they tend to assign their responsibilities to others. Besides, the fact that there is no difference in general indecisiveness and dysfunctional beliefs by locus of control suggests that these factors could be varied. General indecisiveness may have occurred in the form of a personality trait or behavior pattern independent their locus of control.

\section{Conclusions}

The results of this study are believed to contribute to practice related to career decision-making difficulties. It would be effective for psychological counselors working in the field to consider the locus of control as a variable that may affect difficulties students' experience in career decision-making. This study shows that career decision-making difficulties will be influenced by the fact that students have either internal or external locus of control as a personal trait. In addition, this present study will contribute to the literature in case it is performed on a larger sample. In addition, the study was limited to the students in general high school education. A study of the vocational high school could be more useful in that it may provide comparative information. A study that will reveal the intermediary influence of family and environment on the relationship between career decision-making difficulty and locus of control might provide a clearer assessment regarding the results of this study.

\section{REFERENCES}

[1] Albion, M. J. (2000). Career decision making difficulties of adolescent boys and girls. Australian Journal of Career Development, 9(2), 14-19.

[2] Bacanl1, F. (2012). Kariyer karar verme güçlükleri ve meslek seçimine ilişkin akılcı olmayan inançların ilişkisi. Türk Psikolojik Danışma ve Rehberlik Dergisi, 4(37), 86-95.

[3] Bacanl1, F., Eşici, H. \& Özünlü, M. B. (2013). Kariyer karar verme güçlüklerinin çeşitli değişkenlere göre incelenmesi. Türk Psikolojik Danışma ve Rehberlik Dergisi, 5(40), 198-211.

[4] Bacanl1, F. (2016). Career decision-making difficulties of
Turkish adolescents. International Journal for Educational and Vocational Guidance, 16(2), 233-250.

[5] Bullock-Yowell, E., McConnell, A. E., \& Schedin, E. A. (2014). Decided and undecided students: Career self-efficacy, negative thinking, and decision-making difficulties. NACADA Journal, 34(1), 22-34.

[6] Çakır, M. A. (2004). Mesleki karar envanterinin geliştirilmesi. Ankara Üniversitesi Eğitim Bilimleri Fakültesi Dergisi, 37(2), 1-14.

[7] Çoban, A. E., \& Hamamcı, Z. (2006). Kontrol odakları farklı ergenlerin karar stratejileri açısından incelenmesi. Kastamonu Eğitim Dergisi, 14(2), 393-402.

[8] Çolakkadığlu, O., Cenkseven Önder, F., \& Avc1, R. (2011). Ergenlerde kontrol odağını yordamada karar verme ve problem çözmenin rolü. Ç. $\ddot{U}$. Sosyal Bilimler Enstitüsü Dergisi, 20 (2), 317- 330.

[9] Dağ, I. (2002). Kontrol odağı ölçeği (KOÖ): Ölçek geliştirme, güvenirlik ve geçerlik çalışması, Türk Psikoloji Dergisi, 17 (49), 77-90.

[10] Dağ, İ. (1991). Rotter'in İç-DışKontrol Odağ1 Ölçeği (RIDKOÖ)'nin üniversite öğrencileri için güvenirliği ve geçerliği. Psikoloji Dergisi, 7 (26), 10-16

[11] Di Fabio, A. D., Palazzeschi, L., Asulin-Peretz, L., \& Gati, I. (2013). Career indecision versus indecisiveness: Associations with personality traits and emotional intelligence. Journal of Career Assessment, 21(1), 42-56.

[12] Di Fabio, A., Palazzeschi, L., Levin, N., \& Gati, I. (2015). The role of personality in the career decision-making difficulties of Italian young adults. Journal of Career Assessment, 23(2), 281-293.

[13] Doğan, H., \& Bacanli, F. (2012). The effect of a career decision-making group guidance program on career decision-making difficulties. Energy Education Science and Technology Part B: Social and Educational Studies, Special Issue, 1, 912-916.

[14] Durna, U., \& Şentürk, K. F. (2012). Üniversite öğrencilerinin kontrol odaklarını çeşitli değişkenler yardımıyla tespit etmeye yönelik bir çalışma. ZKU Journal of Social Sciences, 8(15), 37-48

[15] Gati, I., \& Saka, N. (2001). High school students' career related decision-making difficulties. Journal of Counseling and Development, 79, 331-340.

[16] Gati, I., \& Asher, I. (2001). The PIC model for career decision making: Prescreening, in-depth exploration, and choice. Contemporary models in vocational psychology: A volume in honor of Samuel H. Osipow, (s 6), 54.

[17] Gati, I., Krausz, M., \& Osipow, S. H. (1996). A taxonomy of difficulties in career decision making. Journal of Counseling Psychology, 43, 510-526.

[18] Gati,I., Gadassi, R., Saka, N., Hadadi, Y., Ansenberg, N., Friedmann, R., \& Asulin-Peretz, L. (2011), Emotional and personality-related aspects of career decision making difficulties: Facets of career indecisiveness. Journal of Career Assessment. 19,1,3-20.

[19] Gordon, C. P. (1996). Adolescent decision making: A broadly based theory and its application to the prevention of 
early pregnancy. Adolescence, 31(123), 561.

[20] Gültekin, M. (2003). Ergenlerde kontrol odağı algısı. Yayınlanmamış Yüksek Lisans Tezi. Bursa: Uludağ Üniversitesi.

[21] Hamamc1, Z., \& Çoban, (2007). Mesleki olgunluk ve mesleki kararsızlığın akılcı olmayan inançlarla ilişkisi. Türk Psikolojik Danışma ve Rehberlik Dergisi 3(27), 31-42.

[22] Hamamc1, Z., Bacanlı, F., \& Doğan, H. (2013). İlköğretim ortaöğretim ve üniversite öğrencilerinin mesleki ve eğitsel kararlarını etkileyen faktörlerin incelenmesi. Elektronik Sosyal Bilimler Dergisi, 44 (44).

[23] Kağıtçıbaşı, Ç. (2010). Benlik, aile ve insan gelişimi kültürel psikoloji. İstanbul: Koç Üniversitesi Yayınları.

[24] Kavas, A. B. (2011). Testing A Model of Career Indecision among University Students Based On Social Cognitive Career Theory (Doctoral dissertation, middle east technical university).

[25] Kırdök O. (2013), Üniversite Öğrenci Adaylarının Üniversite ve Bölüm Tercih Nedenleri, I. Ulusal Işs ve Meslek Danışmanlığı Kongresi, Ankara, ss.20-20

[26] Kırdök, O. (2010). Bilişsel bilgiyi işleme yaklaşımına göre geliştirilen mesleki karar verme programının sınanması. Yayınlanmamış doktora tezi, Çukurova Üniversitesi Sosyal Bilimler Enstitüsü, Adana.

[27] Lease, S. H. (2004). Effect of locus of control, work knowledge, and mentoring on career decision-making difficulties: Testing the role of race and academic institution. Journal of Career Assessment, 12, 239-254.

[28] Millar, R., \& Shevlin, M. (2007). The development and factor structure of a career locus of control scale for use with school pupils. Journal of Career Development, 33(3), 224-249.

[29] Morgan, T., \& Ness, D. (2003). Career decision-making difficulties of first-year students. The Canadian Journal of Career Development, 2(1), 33-39.

[30] Owen, F. K., Kepir, D. D., Özdemir, S., Ulaş, Ö., \& Yılmaz, O. (2012). Üniversite öğrencilerinin bölüm seçme nedenleri. Mersin Universitesi Ĕgitim Fakültesi Dergisi, 8(3).

[31] Özcan - Candangil, S. Ö. \& Ceyhan, A. (2006). Kontrol Odakları Farklı Lise Öğrencilerinin Bazı Kişisel, Sosyal ve Ailesel Özelliklerine Göre Karar Vermede Özsayg1 ve Kayg1 Düzeylerinin İncelenmesi. Anadolu Üniversitesi Sosyal Bilimler Dergisi, 6 (2), 71-87

[32] Öztemel, K. (2012). Kariyer kararsızlığı ile mesleki karar verme öz yetkinlik ve kontrol odağı arasındaki ilişkiler. Gazi Üniversitesi Gazi Ĕgitim Fakültesi Dergisi, 32, 459477.

[33] Öztemel, K. (2013). Lise öğrencilerinin kariyer karar verme güçlüklerinin yordayıcıları olarak algılanan sosyal destek ve cinsiyet. Journal of Turkish Educational Sciences, 11(3).

[34] Özyürek, R., \& Atıc1, M. K. (2016). Üniversite öğrencilerinin meslek seçimi kararlarında kendilerine yardım eden kaynakların belirlenmesi. Türk Psikolojik Danışma ve Rehberlik Dergisi, 2(17).

[35] Pečjak, S., \& Košir, K. (2007). Personality, motivational factors and difficulties in career decision-making in secondary school students. Psihologijske teme, 16(1), 141-158.

[36] Peterson, G. W., Sampson, J. P., Jr., \& Reardon, R. C. (1991). Career development and services: A cognitive approach. Pacific Grove, California: Brooks/Cole.

[37] Saka, N., Gati, I., \& Kelly, K. R. (2008). Emotional and personality-related aspects of career-decision-making difficulties. Journal of Career Assessment, 16(4), 403-424.

[38] Santos, P. J., \& Ferreira, J. A. (2012). Career decision statuses among Portuguese secondary school students: A cluster analytical approach. Journal of Career Assessment, 20(2), 166-181.

[39] Sarikaya, T., \& Khorshid, L. (2009). Üniversite Öğrencilerinin Meslek Seçimini Etkileyen Etmenlerin İncelenmesi: Üniversite Öğrencilerinin Meslek Seçimi. Türk Ĕ̈itim Bilimleri Dergisi, 7(2).

[40] Sauermann, H. (2005). Vocational choice: A decision making perspective. Journal of Vocational Behavior, 66, 273-303.

[41] Shin, Y. J., \& Kelly, K. R. (2015). Resilience and Decision - Making Strategies as Predictors of Career Decision Difficulties. The Career Development Quarterly, 63(4), 291-305.

[42] Slaten, C. D., \& Baskin, T. W. (2014). Examining the impact of peer and family belongingness on the career decision-making difficulties of young adults: A path analytic approach. Journal of Career Assessment, 22(1), 59-74.

[43] Sovet, L., \& Metz, A. J. (2014). Parenting styles and career decision-making among French and Korean adolescents. Journal of Vocational Behavior, 84(3), 345-355.

[44] Şahin, M., Sarı, S. V., Duman, S., Kerimoğlu, U., \& Kocaman, T. (2015). Mesleki Kararsızlığın Yordanmasında Kontrol Odağı ve Mantık Dışı İnançların Rolü. Türk Psikolojik Danışma ve Rehberlik Dergisi, 5(43).

[45] Tagay, Ö. (2014). Career decision-making difficulties in Turkey and the USA. International Journal of Recent Advances in Multidisciplinary Research, 2(2), 232-239.

[46] Walsh, W. B. (2004). Vocational psychology and personality. In B. Schneider \& D. B. Smith (Eds.), Personality and organizations (pp. 141-161). Mahwah, NJ: Erlbaum.

[47] Xu, H., Hou, Z. J., \& Tracey, T. J. (2014). Relation of environmental and self-career exploration with career decision-making difficulties in Chinese students. Journal of Career Assessment, 22(4), 654-665.

[48] Yeşilyaprak, B. (2004). Denetim Odağı (ed. Y. Kuzgun ve D. Deryakulu). Eğitimde Bireysel Farklılıklar. Ankara:Nobel Yayın Dağıtım. 